\title{
Applying Conjoint Analysis to study Attitudes of Thai Government Organisations
}

\author{
Natee Suriyanon and Visuth Chovichien (Department of Civil Engineering, Chulalongkorn University, Thailand)
}

\begin{abstract}
This article presents the application of choice-based conjoint analysis to analyse the attitude of Thai government organisations towards the restriction of the contractor's right to claim compensation for unfavourable effects from undesirable events. The analysis reveals that the organisations want to restrict only 6 out of 14 types of the claiming rights that were studied. The right that they want to restrict most is the right to claim for additional direct costs due to force majeure. They are willing to pay between $0.087 \%-0.210 \%$ of the total project direct cost for restricting each type of contractor right. The total additional cost for restricting all six types of rights that the organisations are willing to pay is $0.882 \%$. The last section of this article applies the knowledge gained from a choice based conjoint analysis experiment to the analysis of the standard contract of the Thai government. The analysis reveals three types of rights where Thai government organisations are willing to forego restrictions, but the present standard contract does not grant such rights.
\end{abstract}

Keywords: choice-based conjoint analysis, attitude, claim, willingness to pay, Thailand.

\section{INTRODUCTION}

Several unpredictable events occurring during the construction period may have unfavourable effects on construction duration and the contractor's expense. Some examples of these events are force majeures, employer's ineffective functions, employer's interference actions, different site conditions, and change in scope of work. Research has revealed that these events are often cited as reasons for claims for compensation. Moreover, the claims due to these events very often initiate conflict and disputes between contracting parties (Diekmann and Nelson, 1985; Semple et al., 1994; Kumaraswamy 1997; Yogeswaran et al.,1998; Kumaraswamy 1998a; Kumaraswamy 1998b; Zaneldin, 2005).

One of the most effective ways to prevent conflicts between contracting parties due to these undesirable events is to let them know, at the very beginning of the project, the types of unfavourable effects that contractors have the right to claim for compensation and the types of unfavourable events that contractors cannot claim by writing contract conditions to cover these issues clearly and completely. One has to be very careful when drafting these contract conditions. Inappropriate granting or restricting the contractor's claiming right can cause problems to contracting parties. For example, if the contract restricts the contractor's right to claim compensation for an unfavourable effect that the employer is willing to bear himself, the employer may be charged an unacceptably high risk premium by the contractor. Moreover, the contractor may have a feeling that the employer is taking advantage of him when there is an inappropriate restriction of his claiming right. As a result the relationship between contracting parties can turn sour. On the other hand, granting the contractor's right to claim compensation for any unfavourable effect that the employer is not willing to bear himself can also cause problems to the employer in managing and handling this unallocated risk (Ashley et al., 1989; Jergeas and Hartman, 1996; Akintoye and MacLeod, 1997; Mohamed and Hartman, 2000; ACEC/AGC, 2005).

It is important to obtain data on the attitudes of employers and of contractors towards the restriction of the contractor's right to claim for compensation as well as data on the risk premium that the employers are willing to pay and that the contractors require. These data are necessary for considering whether each type of the contractor's right to claim for compensation should be restricted or granted by contract. Having data on the attitude of employers and of contractors towards the restriction of the contractor's right allows one to determine which type of right should or should not be restricted. The contract absolutely should not restrict the contractor's claiming right if the employer does not want to restrict it. In other words, the type of effect that the employer does not think the contractor should be responsible for should be assigned to the employer. There is no reason to assign this responsibility to the contractor if the employer is comfortable in taking the responsibility. Moreover, the restriction of the contractor's right to claim compensation for this effect will cost the employer an unnecessary extra expense (Ashley et al., 1989; Jergeas and Hartman, 1996; Akintoye and MacLeod, 1997; Mohamed and Hartman, 2000). On the other hand, the contract should restrict the contractor's claiming right if the contractor does not require it to be granted. This is because the contractor realises that it is his responsibility and he is comfortable in taking the responsibility for this type of unfavourable effect.

In case the employers think the contractor's right to claim for compensation should be restricted but the contractors do not think so, the data on risk premiums that employers are willing to pay (WTP) and that the contractors want (RP) are required for the decision on whether to restrict the contractor's right to claim for compensation. In this situation, the decision on whether to grant or to restrict the contractor's right to claim should be made based on a comparison of these two data. There certainly should be no restriction of the contractor's right to claim if the premium that employers are willing to pay is less than the premium that contractors would like to get. This is because the restriction of the right will cost employers more what that they think is reasonable. On the other hand, if the premium that employers are willing to pay is more than the premium that contractors would like to get, the contractor's right to claim should certainly be restricted. Restriction of the right will cost employers less than that which they expect to shoulder (Ward et al., 1991; Jergeas and Hartman, 1996; Downs and Kettle, 2008).

\section{LITERATURE REVIEW}

The literature review reveals insight on the attitude of contracting parties toward the responsibility for overall effect from undesirable events. Some examples of the research in this area are the studies by Kartam and Kartam (2001), Rahman and Kumaraswamy 
(2002), Bing et al. (2004), ANDI (2006), El-Sayegh (2007), and Loosemore and McCarthy (2008). Although the results of the studies by these researchers fulfil their objectives, the decision whether to grant or to restrict the contractor's right to claim compensation for specific type of unfavourable effects from undesirable events could not be made. This is because the research in the past did not study the attitude of contracting parties towards each specific effect of undesirable events, such as the effect on project duration, the effect on direct cost and the effect on indirect cost.

There have been rather limited studies of risk premium. Some examples are the studies by Ashley et al. (1989), Akintoye and MacLeod (1997), Khan (1998), and Mohamed and Hartman (2000). The knowledge gained from these studies also cannot be used for considering whether to grant or to restrict the contractor's right to claim for compensation for unfavourable effects due to undesirable events. This is because these researchers did not focus on the premium related to the restriction of the contractor's right to claim for each specific effect from the undesirable events. Moreover, in most of the research studies in this area, such as the studies by Ashley et al. (1989) and by Akintoye and MacLeod (1997), a discrete rating scale was used. Therefore, the results of these research studies on risk premium that the employer is willing to pay or that the contractor wants to get could not be expressed numerically and could not be used for comparison.

As already mentioned, the data on the attitude of the contracting parties (i.e. employers and contractors) and the risk premium obtained from past research are not complete and cannot be used for considering whether to grant or to restrict the contractor's right to claim compensation for unfavourable effects due to undesirable events. To obtain data that can be used for considering whether to grant or restrict contractor's rights, further research is needed.

\section{RESEARCH OBJECTIVES}

This study is a part of our whole research project that aims to propose an approach to improve the contract conditions of the standard contract of the Thai government. This standard contract form is used in most of the construction projects owned by the Thai government which is the biggest group of employers in the Thai construction industry. The Thai government's annual budget for construction in the year 2009 is 166,000 million Baht. This equals about $50 \%$ of the total cost of construction for the whole country. This research project focuses on the responsibility of the contracting parties for the unfavourable effects from five groups of events that normally initiate disputes between contracting parties in the Thai construction industry. These events are force majeures employer's ineffective functions, employer's interference actions, different site conditions, and change in scope of work.

The primary objectives of this part of the project are to investigate the attitude of employers (Thai governmental organisations) towards the restriction of the contractor's rights to claim compensation for unfavourable effects due to undesirable events and to determine the risk premium that they are willing to pay for the restriction. These data are required for considering whether the contractor's right to claim for compensation should be restricted. By using data on the attitude of employers towards the restriction of the contractor's right to claim for compensation, the types of the effect that employers are comfortable to take responsibility for themselves can be identified. The types of contractor's right to claim for compensation that certainly should not be restricted will then be known. On the other hand, data on the risk premium that the employer is willing to pay for the restriction of the contractor's right to claim are also required for comparing the premium that the contractor wants when both contracting parties do not want to be responsible for an effect of an undesirable event. The secondary objective of this part of the study is to apply the knowledge gained from the study to a preliminary analysis of the inappropriateness of conditions related to the responsibility allocation in the standard contract of the Thai government ${ }^{1}$.

\section{CHOICE-BASED CONJOINT ANALYSIS}

\section{GENERAL INFORMATION ABOUT CHOICE-BASED CONJOINT ANALYSIS}

Choice-based conjoint analysis is one of the statistical techniques and methods that were designed to analyse the utility of each characteristic of each specific attribute of product. It is used in several research studies (Hartmann and Sattler, 2002; Sawtoothsoftware, 2007). Choice-based conjoint analysis is not only used in marketing research, but in other research such as environmental valuation. As for civil engineering, choice-based conjoint analysis is widely applied in transportation research. However, in the field of construction and management, Sturts and Griffis (2005) is the only study that applied choice-based conjoint analysis, in this case to calculate the probability of winning based on multiple factors.

The unique feature of choice-based conjoint analysis is that it does not require respondents to identify the degree of importance of each possible level of each specific attribute of the product. Instead, they are asked to express their preferences by choosing the most preferred product (service) - one choice out of a specified choice set. Then, a multinomial logit model, developed based on random utility theory, is used to investigate all the utility data.

The independent variable that is used in developing a multinomial logit model is the total observable utility of each choice. It is the summation of the utility of each attribute of each choice, which can be expressed as shown in Equation (1).

$V_{i}=\quad \beta_{1 i}\left(X_{1 i}\right)+\beta_{2 i}\left(X_{2 i}\right)+\beta_{3 i}\left(X_{3 i}\right)+\ldots \ldots+\beta_{k i}\left(X_{k i}\right)$

where:

$V_{i} \quad$ is the observable utility for choice $i$

$k$ is the number of the attributes of the product/service

$X_{n i} \quad$ is the values of the attributes $n$ of the choice $i$

$\beta_{n i} \quad$ is the utility of the attributes $n$ of the choice $i$

The multinomial logit model then is developed based on the probability of selecting each choice. The probability of an individual choosing choice $i$ out of the choice set is equal to the ratio of the (exponential of the) utility of choice $i$ to the sum of the (exponential of) utility of all choices in the choice set. The model of the probability of selecting each choice is presented in Equation (2).

$$
P_{n}(i \mid C)=\frac{\exp (V(i))}{\sum_{i=1}^{J} \exp (V(j))}
$$

where:

$P_{n}(i \mid C)$ is the probability of an individual choosing choice $i$ out of the choice set

$\mathrm{V}$ (i) is the utility for choice $i$

$\mathrm{J}$ is the number of a choice in the choice set

C is the choice set that the respondent is asked to evaluate

\footnotetext{
${ }^{1}$ The complete analysis of the inappropriateness of the contract conditions will be reported later when data on the attitude of Thai contractors towards the restriction of the rights is obtained.
} 
Once the utility of each specific attribute of a product/service is estimated, the marginal rate of substitution between different attributes can be calculated. If one of the attributes is a monetary variable, the willingness of the respondent to pay for each specific attribute of the product/service can be calculated from Equation (3).

$$
W T P_{n}=\frac{-\beta_{n}}{\beta_{P R I}}
$$

where:

WTP is the monetary value that an individual is willing to pay for a unit change of attribute $n$

$\beta_{n} \quad$ is the utility of attribute $n$

$\beta_{\mathrm{PRI}} \quad$ is the utility of monetary attributes

\section{A CHOICE-BASED CONJOINT ANALYSIS APPROACH TO STUDY THE ATTITUDES OF THAI GOVERNMENT ORGANISATIONS}

The desire of the organisations to restrict each type of contractor's right to claim for compensation and extra cost that the organisations are willing to pay for the restriction of each type of the contractor's claiming right (WTP) are the two main results that are expected from the study of the attitudes of Thai government organisations toward the restriction of the contractor's right to claim for compensation. Choice-based conjoint analysis is one of the most suitable statistical tools that can provide these two types of information. The utility value of the restriction of the claiming right and the utility value of the premium rate to be paid to a contractor of Thai government organisations can be determined from the multinomial model of the choice-based conjoint analysis assuming that the proposal related to restriction of the claiming right and paying the premium is the product, the attributes of the proposal are product attributes, and the characteristics of each specific attribute of the proposal are characteristic of specific product attributes. Figure 1 reveals an analogy with a consumer product, i.e. a dog food, with a proposal related to the restriction of the right to claim for compensation and the premium.

Once the utility of the restriction of each type of contractor's claiming right and that of the premium rate are estimated, the willingness of the organisations to restrict each type of the contractor's claiming right can be identified by examining the sign of their utility value. The WTP for restricting each type of contractor's right can also be calculated from the comparison of the utility of restricting the right with the utility of paying a premium to the contractor.

\section{RESEARCH DESIGN AND DATA COLLECTION}

\section{PROPOSED ATTITUDES AND CHARACTERISTICS}

Generally, two types of fundamental information are required for designing a choice-based conjoint analysis study. These are the list of the product attributes and the list of the characteristics of each product attribute. For this research, to study the attitudes of the organisations toward the restriction of the contractor's right to claim compensation for an unfavourable effect from the five undesirable events, these two types of information, therefore, are the list of proposal attributes and the list of the characteristics of each proposal attribute.

The proposal to be studied here consists of six attributes. The first five attributes are conditions related to the restriction of the contractor's right to claim compensation for unfavourable effects from the five undesirable events. These five events are the events that have effects on construction duration and contractor's expense and normally initiate conflict between contracting parties in the Thai construction industry. These five groups of events are acquired from the study of three groups of documents namely: (1) the rulings of Thai Supreme Court between 1957 and 2001, (2) the decisions of the Office of the Attorney General between 1957 and 2001 and the decisions of the Regulatory Authorities on the Procurement Regulations of the Prime Minister's Office, and (3) seven standard contracts.

These five events are (1) force majeure such as hurricane, flood, etc, (2) ineffective performances of employer such as delay in approval of submittal, (3) interference to the work by employer's actions such as giving an order to suspend the project, or occupying the construction area within the site, (4) differing site conditions such as experiencing an existing underground foundation in the construction area, and (5) change in the scope of work such as the employer giving an order to increase the quantity of the work. The last attribute was a condition related to the premium rate that the organisations have to pay to the contractor to compensate for the restriction of the right to claim for compensation.

Figure 1: The attributes and the characteristics of an attribute of a dog food versus those of a proposal related to the restriction of the right to claim for compensation and the premium



6 ounce
12 ounce

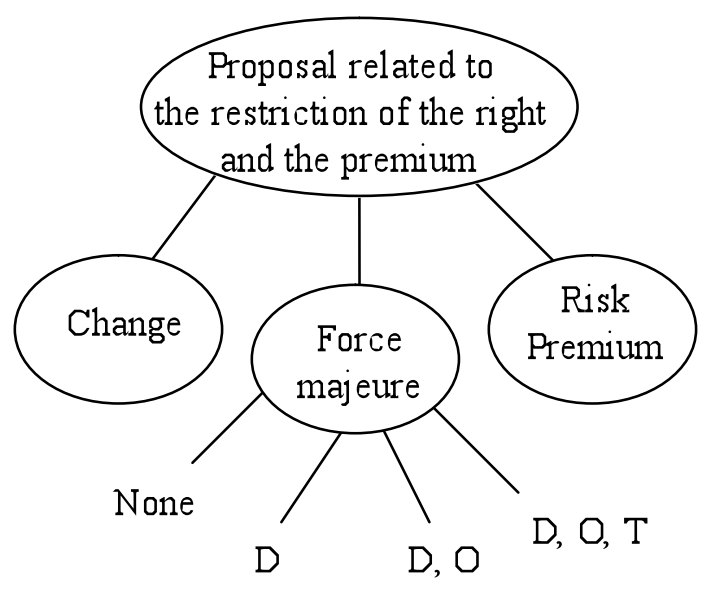

Note: $\mathrm{D}=$ Direct cost, $\mathrm{O}=$ Overhead cost, $\mathrm{T}=$ Time 
This research focused on three types of restrictions. The characteristics of the restrictions are as follows: (1) the restriction of contractor's right to claim for an increase of direct cost, (2) the restriction of contractor's right to claim for an increase of overhead cost, and (3) the restriction of contractor's right to claim for an extension of construction duration. The four levels of the restriction of the right to claim compensation for unfavourable effects of each undesirable event were derived from the approaches widely used in the Thai construction industry. The detail of the combination of the these characteristics of restriction and the four levels of restriction are presented in Table 1. In this study, the premium rate was also categorized into four levels, ranging from $0.25 \%$ to $1.00 \%$ of the project direct cost. The full list of the premium rates and the characteristic of the premium rates are also presented in Table 1.

Table 1: List of the proposal attributes and the characteristic of each attribute

\begin{tabular}{|c|c|c|}
\hline & List of the attributes of the proposal & $\begin{array}{l}\text { Parameter representing } \\
\text { the restriction/premium }\end{array}$ \\
\hline First attribute: & $\begin{array}{l}\text { Restriction of contractor's right to claim compensation } \\
\text { for unfavorable effect from force majeure }\end{array}$ & \\
\hline First level: & No restriction of contractor's claiming right & - \\
\hline Second level: & $\begin{array}{l}\text { Restriction of contractor's right to claim for an increase of } \\
\text { direct cost }\end{array}$ & FORD \\
\hline Third level: & $\begin{array}{l}\text { Restriction of contractor's right to claim for an increase of } \\
\text { direct cost and an increase of overhead cost }\end{array}$ & FORD, FORO \\
\hline Fourth level: & $\begin{array}{l}\text { Restriction of contractor's right to claim for an increase of } \\
\text { direct cost, an increase of overhead cost and an extension of } \\
\text { construction duration }\end{array}$ & FORD, FORO, FORT \\
\hline Second attribute: & $\begin{array}{l}\text { Restriction of contractor's right to claim compensation } \\
\text { for unfavorable effect from ineffective performance of } \\
\text { employer }\end{array}$ & \\
\hline First level: & No restriction of contractor's claiming right & - \\
\hline Second level: & $\begin{array}{l}\text { Restriction of contractor's right to claim for an increase of } \\
\text { direct cost }\end{array}$ & IEFD \\
\hline Third level: & $\begin{array}{l}\text { Restriction of contractor's right to claim for an increase of } \\
\text { direct cost and an increase of overhead cost }\end{array}$ & IEFD, IEFO \\
\hline Fourth level: & $\begin{array}{l}\text { Restriction of contractor's right to claim for an increase of } \\
\text { direct cost, an increase of overhead cost and an extension of } \\
\text { construction duration }\end{array}$ & IEFD, IEFO, IEFT \\
\hline Third attribute: & $\begin{array}{l}\text { Restriction of contractor's right to claim compensation } \\
\text { for unfavorable effect from interference of the work by } \\
\text { the employer's action }\end{array}$ & \\
\hline First level: & No restriction of contractor's claiming right & - \\
\hline Second level: & $\begin{array}{l}\text { Restriction of contractor's right to claim for an increase of } \\
\text { overhead cost }\end{array}$ & INTD \\
\hline Third level: & $\begin{array}{l}\text { Restriction of contractor's right to claim for an increase of } \\
\text { direct cost and an increase of overhead cost }\end{array}$ & INTD, INTO \\
\hline Fourth level: & $\begin{array}{l}\text { Restriction of contractor's right to claim for an increase of } \\
\text { direct cost, an increase of overhead cost and an extension of } \\
\text { construction duration }\end{array}$ & INTD, INTO, INTT \\
\hline Fourth attribute: & $\begin{array}{l}\text { Restriction of contractor's right to claim compensation } \\
\text { for unfavorable effect from differing site condition }\end{array}$ & \\
\hline First level: & No restriction of the contractor's claiming right & - \\
\hline Second level: & $\begin{array}{l}\text { Restriction of contractor's right to claim for an increase of } \\
\text { overhead cost }\end{array}$ & DIFO \\
\hline Third level: & $\begin{array}{l}\text { Restriction of contractor's right to claim for an increase of } \\
\text { direct cost and an increase of overhead cost }\end{array}$ & DIFD, DIFO \\
\hline Fourth level: & $\begin{array}{l}\text { Restriction of contractor's right to claim for an increase of } \\
\text { direct cost, an increase of overhead cost and an extension of } \\
\text { construction duration }\end{array}$ & DIFD, DIFO, DIFT \\
\hline Fifth attribute: & $\begin{array}{l}\text { Restriction of contractor's right to claim compensation } \\
\text { for unfavorable effect from change in scope of work }\end{array}$ & \\
\hline First level: & No restriction of the contractor's claiming right & - \\
\hline Second level: & $\begin{array}{l}\text { Restriction of contractor's right to claim for an increase of } \\
\text { overhead cost }\end{array}$ & $\mathrm{CHAO}$ \\
\hline Third level: & $\begin{array}{l}\text { Restriction of contractor's right to claim for an increase of } \\
\text { construction duration }\end{array}$ & CHAT \\
\hline Fourth level: & $\begin{array}{l}\text { Restriction of contractor's right to claim for an increase of } \\
\text { overhead cost and an extension of construction duration }\end{array}$ & $\mathrm{CHAO}, \mathrm{CHAT}$ \\
\hline Sixth attribute: & $\begin{array}{l}\text { Premium rate that the organisation has to pay to } \\
\text { contractor }\end{array}$ & PRE \\
\hline First level: & $1.00 \%$ of total project direct cost & \\
\hline Second level: & $0.75 \%$ of total project direct cost & \\
\hline Third level: & $0.50 \%$ of total project direct cost & \\
\hline Fourth level: & $0.25 \%$ of total project direct cost & \\
\hline
\end{tabular}




\section{QUESTIONNAIRE DESIGN}

The development of the questionnaire began with determining the number of proposals to be considered. Since there are 4 levels of condition for each proposal attribute, a total of $4^{6}=4,096$ proposals can be developed. It was seemingly impossible to ask respondents to evaluate such large number of proposals; therefore, fractional factorial design was used to reduce the number of hypothetical proposals to be evaluated by respondents. To ensure that $100 \%$ D-efficiency would be acquired, SAS ver. 9.0 was used to determine the number of proposals and to develop the proposal. The results from mktrun in SAS revealed that the appropriate number of proposals is 48 . All 48 proposals were, then, developed by mktex in SAS.

To develop the multinomial logit model, it is necessary that the number of available equations is more than the number of parameters. In this research, there are $15\left(3^{*} 4+2+1\right)$ utility parameters. Therefore, all of the 48 proposals are paired up to be 24 choice sets. These provide 24 equations that are more than the number of utility parameters, which is 15 . However, it is taken into account that the respondents may feel uninterested and become inattentive when asked to evaluate a large number of choice sets. This feeling may have affect responses (Hensher et al. 2005). To avoid any errors due to this attitude, the 24 choice sets are divided into two groups. Each group consists of 12 choice sets and each respondent is asked to respond only to one group. An example of a choice set presented to the respondents to identify the most preferred proposal is presented in Figure 2.
SAMPLES FOR THE STUDY AND THE SURVEY CONCERNING ATTITUDES OF THAI GOVERNMENT ORGANISATIONS

To gather the data on the attitudes of Thai government organisations toward restriction of contractor's right to claim for compensation, the questionnaire survey was conducted during June 2008 to August 2008. Selected samples for the study are the individuals who represent Thai government organisations on construction projects. Those who worked for engineering consultant companies and hired by Thai government organisations are also included in the study sample. Information about the organisations, the number of their personnel to whom the questionnaires were distributed, and the number of respondents is presented in Table 2.

The total number of returned questionnaires that met the criteria for inclusion in this research is 317 . This is more than the minimum required response. According to the Rich Johnson formula (Orme, 2006), the minimum number of respondents required is 84 , as given by Equation (4).

$\frac{n t a}{c} \geq 500$

where:

$\mathrm{n} \quad$ is minimum number of respondent

$t \quad$ is number of choice set

a is number of choice in each choice set

c is number of level of each attribute

Figure 2: Example of choice set presented to respondents

Choice set 1

\begin{tabular}{|c|c|}
\hline $\begin{array}{l}\text { Conditions related to the restri } \\
\text { claim compensation for unfave }\end{array}$ & $\begin{array}{l}\text { tion of contractor's right to } \\
\text { able effect from each event }\end{array}$ \\
\hline & An increase of direct cost \\
\hline Force majeure & An increase of overhead cost \\
\hline such as hurricane, flood, etc. & $\begin{array}{l}\text { An extension of construction } \\
\text { duration }\end{array}$ \\
\hline Ineffective performances of & An increase of direct cost \\
\hline employer & An increase of overhead cost \\
\hline $\begin{array}{l}\text { such as delay in approval } \\
\text { of submittal }\end{array}$ & $\begin{array}{l}\text { An extension of construction } \\
\text { duration }\end{array}$ \\
\hline & An increase of direct cost \\
\hline The & An increase of overhead cost \\
\hline & $\begin{array}{l}\text { An extension of construction } \\
\text { duration }\end{array}$ \\
\hline Differing site conditions & An increase of direct cost \\
\hline such as experiencing an & An increase of overhead cost \\
\hline $\begin{array}{l}\text { existing underground } \\
\text { foundation }\end{array}$ & $\begin{array}{l}\text { An extension of construction } \\
\text { duration }\end{array}$ \\
\hline & An increase of direct cost \\
\hline Change in scope of work & An increase of overhead cost \\
\hline such as additional work order & $\begin{array}{l}\text { An extension of construction } \\
\text { duration }\end{array}$ \\
\hline
\end{tabular}

Please identify your most preferred proposal of the two by marking $X$ in the block

\begin{tabular}{|c|}
\hline $\begin{array}{c}\text { First } \\
\text { proposal }\end{array}$ \\
\hline Restriction \\
\hline Restriction \\
\hline No restriction \\
\hline Restriction \\
\hline Restriction \\
\hline No restriction \\
\hline Restriction \\
\hline Restriction \\
\hline Restriction \\
\hline Restriction \\
\hline Restriction \\
\hline No restriction \\
\hline No restriction \\
\hline Restriction \\
\hline No restriction \\
\hline proposal \\
\hline First \\
\hline
\end{tabular}

\begin{tabular}{|c|}
\hline $\begin{array}{c}\text { Second } \\
\text { proposal }\end{array}$ \\
\hline Restriction \\
\hline No restriction \\
\hline No restriction \\
\hline No restriction \\
\hline No restriction \\
\hline No restriction \\
\hline No restriction \\
\hline No restriction \\
\hline No restriction \\
\hline No restriction \\
\hline No restriction \\
\hline No restriction \\
\hline No restriction \\
\hline No restriction \\
\hline Restriction \\
\hline proposal \\
\hline Second \\
\hline
\end{tabular}


Table 2: List of the proposal attributes and the characteristic of each attribute

\begin{tabular}{|c|c|c|c|c|c|c|}
\hline \multirow[t]{2}{*}{ No } & \multirow{2}{*}{$\begin{array}{c}\text { Type of } \\
\text { organisation }\end{array}$} & \multicolumn{2}{|c|}{ No. of organizations: } & \multicolumn{2}{|c|}{ No. of personnel: } & \multirow{2}{*}{$\begin{array}{c}\text { No. of surveys: } \\
\text { that met the } \\
\text { criteria }\end{array}$} \\
\hline & & $\begin{array}{l}\text { to which } \\
\text { surveys } \\
\text { were } \\
\text { distributed }\end{array}$ & $\begin{array}{l}\text { responding } \\
\text { to survey }\end{array}$ & $\begin{array}{l}\text { to which } \\
\text { surveys } \\
\text { were } \\
\text { distributed }\end{array}$ & $\begin{array}{l}\text { responding } \\
\text { to survey }\end{array}$ & \\
\hline 1. & Public university & 23 & 17 & 60 & 32 & 32 \\
\hline 2. & $\begin{array}{l}\text { Division of highway } \\
\text { department }\end{array}$ & 54 & 50 & 253 & 144 & 137 \\
\hline 3. & $\begin{array}{l}\text { Division of irrigation } \\
\text { department }\end{array}$ & 10 & 9 & 40 & 23 & 23 \\
\hline 4. & $\begin{array}{l}\text { Local administration } \\
\text { unit }\end{array}$ & 64 & 53 & 198 & 98 & 97 \\
\hline 5. & $\begin{array}{l}\text { Construction } \\
\text { consulting company }\end{array}$ & 40 & 15 & 123 & 30 & 28 \\
\hline & Total & 191 & 144 & 674 & 327 & 317 \\
\hline
\end{tabular}

\section{RESULTS OF THE STUDY AND DISCUSSION}

\section{MULTINOMIAL LOGIT MODEL AND THE UTILITY PARAMETERS}

In this research, there are a total of 15 utility parameters that need to be evaluated. Those parameters are 14 utility parameters related to restriction of the contractor's rights and one other parameter related to the premium rate. The multinomial logit model as presented in Equation (5) is developed by applying the program SAS.

$$
\begin{aligned}
& V(i)=\beta_{\text {FORD }}(\text { FORD })+\beta_{\text {FORO }}(\text { FORO })+\beta_{\text {FORT }}(\text { FORT })+ \\
& \beta_{\text {IEFD }}(\text { IEFD })+\beta_{\text {IEFO }}(\text { IEFO })+\beta_{\text {IEFT }} \text { (IEFT) }+ \\
& \beta_{\text {INTD }}(\text { INTD })+\beta_{\text {INTO }}(\text { INTO })+\beta_{\text {INTT }}(\text { INTT })+ \\
& \beta_{\text {DIFD }}(\text { DIFD })+\beta_{\text {DIFO }}(\text { DIFO })+\beta_{\text {DIFT }}(\text { DIFT })+ \\
& \beta_{\text {CHAO }}(\mathrm{CHAO})+\beta_{\text {CHAT }}(\mathrm{CHAT})+\beta_{\mathrm{PRE}}(\mathrm{PRE})
\end{aligned}
$$

The value of each of the 15 utility parameters, which is developed based on the response rate for each choice, is presented in Table 3.

\section{THE ATTITUDE OF THAI GOVERNMENT ORGANISATIONS TOWARDS THE RESTRICTION OF THE CONTRACTOR'S RIGHT TO CLAIM COMPENSATION}

The plus or minus sign of the utility parameter reflects the attitude of the respondents. A plus sign indicates that the respondents prefer that type of attribute characteristic. A minus sign indicates that the respondents do not prefer that type of attribute characteristic. Therefore, in this research, the attitude of Thai government organisations can be interpreted from the sign of each utility parameter.

The sign of each utility parameter in Table 3 reveals that there are six types of contractor's right to claim for compensation that Thai government organisations would like to restrict. Of these six types, two of them are related to force majeure. These are the right to claim for an increase of direct cost and an increase of overhead cost. One of them is related to employer's ineffective performances: the right to claim for an increase of overhead cost. Moreover, two of them are related to employer's interference actions. These are the right to claim for an increase of direct cost and an increase of overhead cost. Lastly, the remaining one is related to differing site conditions; it is the right to claim for an increase of overhead cost.
On the other hand, according to data in Table 3, there were 8 types of contactor's claiming right that Thai government organisations did not want to restrict. Of these eight types of right, one is related to force majeure: it is the right to claim for an extension of construction duration. Two of them are related to employer's ineffective performances: the right to claim for an increase of direct cost and an extension of construction duration. One of them is related to employer's interference actions: the right to claim for an extension of construction duration. Two of them are related to differing site conditions: the right to claim for an increase of direct cost and an extension of construction duration. The last two are related to change in scope of the work: the right to claim for an increase of the overhead cost and an extension of construction duration.

Based on data from the analysis, it appears that Thai government organisations are less concerned about extension of the construction duration. The results of the study reveal that the organisations did not mind granting the contractor's right to claim for the extension of construction duration in all five cases. This could be because the government organisations have more flexibility and probably less "urgency" as to their "commencement of use" of the project than private organisations. On the other hand, Thai government organisations tend to pay much more attention to extra cost. Based on data from the analysis, Thai government organisations agreed to pay only an increase of direct cost due to employer's ineffective performance, differing site conditions, and change in scope of work. These study results reflect the willingness of the representatives of government organisations to follow the regulation of the Thai government that encourages them to manage projects within budget limits and prohibits them from requesting extra budget. They also reflect the intention of the organisations to avoid disputes with contractors that might occur during the assessment of the actual expense due to an event.

\section{THE ATTITUDE OF THAI GOVERNMENT ORGANISATIONS TOWARD THE CONTRACTOR'S PREMIUM}

As shown in Table 3, the utility value of paying a contractor's premium was less than zero. It indicates that increasing the contractor's premium will make the organisations unhappy. This information conforms to the fact that employers prefer not to pay high premiums to contractors. 
Table 3: Value of each utility parameter related to the restriction of the contractor's right to claim for compensation and the premium rate

\begin{tabular}{|c|c|c|}
\hline Parameter & Description of the parameter & Value \\
\hline$\beta_{\mathrm{FORD}}$ & $\begin{array}{l}\text { Utility of restriction of the right to claim for an increase of } \\
\text { direct cost due to force majeure }\end{array}$ & 0.224 \\
\hline$\beta_{\mathrm{FORO}}$ & $\begin{array}{l}\text { Utility of restriction of the right to claim for an increase of } \\
\text { overhead cost due to force majeure }\end{array}$ & 0.176 \\
\hline$\beta_{\mathrm{FORT}}$ & $\begin{array}{l}\text { Utility of restriction of the right to claim for an extension } \\
\text { of construction duration due to force majeure }\end{array}$ & -0.713 \\
\hline$\beta_{\mathrm{IEFD}}$ & $\begin{array}{l}\text { Utility of restriction of the right to claim for an increase of } \\
\text { direct cost due to employer's ineffective performances }\end{array}$ & -0.005 \\
\hline$\beta_{\mathrm{IEFO}}$ & $\begin{array}{l}\text { Utility of restriction of the right to claim for an increase of } \\
\text { overhead cost due to employer's ineffective } \\
\text { performances }\end{array}$ & 0.096 \\
\hline$\beta_{\mathrm{IEFT}}$ & $\begin{array}{l}\text { Utility of restriction of the right to claim for an extension } \\
\text { of construction duration due to employer's ineffective } \\
\text { performances }\end{array}$ & -0.105 \\
\hline$\beta_{\text {INTD }}$ & $\begin{array}{l}\text { Utility of restriction of the right to claim for an increase of } \\
\text { direct cost due to employer's interference actions }\end{array}$ & 0.093 \\
\hline$\beta_{\text {INTO }}$ & $\begin{array}{l}\text { Utility of restriction of the right to claim for an increase of } \\
\text { overhead cost due to employer's interference actions }\end{array}$ & 0.141 \\
\hline$\beta_{\mathrm{INTT}}$ & $\begin{array}{l}\text { Utility of restriction of the right to claim for an extension } \\
\text { of construction duration due to employer's interference } \\
\text { actions }\end{array}$ & -0.118 \\
\hline$\beta_{\text {DIFD }}$ & $\begin{array}{l}\text { Utility of restriction of the right to claim for an increase of } \\
\text { direct cost due to differing site conditions }\end{array}$ & -0.159 \\
\hline$\beta_{\text {DIFO }}$ & $\begin{array}{l}\text { Utility of restriction of the right to claim for an increase of } \\
\text { overhead cost due to differing site conditions }\end{array}$ & 0.213 \\
\hline$\beta_{\text {DIFT }}$ & $\begin{array}{l}\text { Utility of restriction of the right to claim for an extension } \\
\text { of construction duration due to differing site conditions }\end{array}$ & -0.022 \\
\hline$\beta_{\mathrm{CHAO}}$ & $\begin{array}{l}\text { Utility of restriction of the right to claim for an increase of } \\
\text { overhead cost due to change in scope of work }\end{array}$ & -0.087 \\
\hline$\beta_{\text {CHAT }}$ & $\begin{array}{l}\text { Utility of restriction of the right to claim for an extension } \\
\text { of construction duration due to change in scope of work }\end{array}$ & -0.041 \\
\hline$\beta_{\mathrm{PRE}}$ & $\begin{array}{l}\text { Utility of paying premium rate as a proportion to the total } \\
\text { project direct cost. }\end{array}$ & -1.070 \\
\hline
\end{tabular}

RANKING THE PREFERENCE OF THAI GOVERNMENT ORGANISATIONS FOR THE RESTRICTION OF EACH TYPE OF CONTRACTOR'S RIGHT

The level of preference of the respondents for each characteristic of product attributes can be evaluated from the value of utility parameter related to them. The ranking of willingness of Thai government organisations to restrict each type of contractor's claiming right, then, can be performed by comparing the value of the related parameters. High values of utility parameter reveal that Thai government organisations are eager to restrict that type of contractor's right to claim for compensation.
The types of contractor's claiming right that Thai government organisations would like to restrict can be ranked according to the level of the willingness to restrict as shown in Table 4.

THE WILLINGNESS OF THAI GOVERNMENT ORGANISATIONS TO PAY FOR THE RESTRICTION OF THE CONTRACTOR'S RIGHT TO CLAIM FOR COMPENSATION

Table 5 presents Thai government organisations willingness to pay for the restriction of six types of the contractor's right to claim for compensation (WTP). These six types of contractor's right to claim for compensation are the types of contractor's rights that the organisations would like to restrict. WTP is presented in terms 
Table 4: Ranking of the claiming rights by the level of willingness of Thai government organisations to restrict

\begin{tabular}{cl}
\hline Ranking & \multicolumn{1}{c}{ Description } \\
\hline 1 & $\begin{array}{l}\text { the right to claim for an increase of direct cost due to force majeure } \\
\text { the right to claim for an increase of overhead cost due to differing site } \\
\text { conditions }\end{array}$ \\
\hline 3 & $\begin{array}{l}\text { the right to claim for an increase of overhead cost due to force majeure } \\
\text { the right to claim for an increase of overhead cost due to employer's } \\
\text { interference actions }\end{array}$ \\
\hline 5 & $\begin{array}{l}\text { the right to claim for an increase of direct cost due to employer's } \\
\text { interference actions } \\
\text { the right to claim for an increase of overhead cost due to employer's } \\
\text { ineffective performances }\end{array}$ \\
\hline
\end{tabular}

Table 5: Willingness of Thai government organizations to pay for the restriction of each type of the contractor's right to claim for compensation

\begin{tabular}{lc}
\hline \multicolumn{1}{c}{ Description } & WTP \\
\hline $\begin{array}{l}\text { Restriction of the right to claim for an increase of direct cost due to force } \\
\text { majeure }\end{array}$ & 0.210 \\
$\begin{array}{l}\text { Restriction of the right to claim for an increase of overhead cost due to force } \\
\text { majeure }\end{array}$ & 0.164 \\
\hline $\begin{array}{l}\text { Restriction of the right to claim for an increase of overhead cost due to } \\
\text { employer's ineffective performances }\end{array}$ & 0.090 \\
\hline $\begin{array}{l}\text { Restriction of the right to claim for an increase of direct cost due to } \\
\text { employer's interference actions } \\
\text { Restriction of the right to claim for an increase of overhead cost due to } \\
\text { employer's interference actions }\end{array}$ & 0.087 \\
\hline $\begin{array}{l}\text { Restriction of the right to claim for an increase of overhead cost due to } \\
\text { differing site conditions }\end{array}$ & 0.199 \\
\hline
\end{tabular}

of percentages of the total project direct cost. These values were determined by applying Equation (3). The WTP values in Table 5 reveal that the organisations are willing to pay between $0.087 \%$ $0.210 \%$ of the total project direct cost to restrict each type of the contractor's right. The total extra cost that the organisations are willing to pay to compensate for the restriction of all the six types of contractor's right to claim is $0.882 \%$.

\section{ANALYSIS OF THE STANDARD CONTRACT OF THE THAI GOVERNMENT}

In this section, the standard contract of the Thai government, known as "the sample contract annexed to the procurement regulation of the Prime Minister's office", was analysed on the knowledge gained from the choice-based conjoint analysis experiment. This contract form is used in most projects owned by Thai government organisations and state enterprises.

Of the ten types of right to claim for compensation, the standard contract of the Thai government mentions seven. Clause 11 of the contract restricts the contractor's right to claim for an increase of direct cost and overhead cost due to force majeure. Clause 16 of the contract allows the contractor to claim for an extension of construction duration and an increase of overhead cost due to change in scope of work. Clause 22 of the contract allows the contractor to claim for an extension of construction duration due to force majeure, an extension of construction duration due to the employer's ineffective performances and an extension of construction duration due to the employer's interference actions.

Regarding the other seven types of right not included in the contract, it can be assumed that these types of right are restricted by the contract. This assumption is based on the fact that, by nature, the representatives of Thai government organisations will not allow the contractor to claim for compensation if there is no clear clause in the contract granting the right to claim to the contractor. In addition, Thai constructors tend to avoid a litigation process against the Thai government because they do not want to be blacklisted by the Thai government which as a consequence could bar them from participating on future Thai government projects. 
The following are the results of the study on the comparison of the contractor's right to claim for compensation according to the standard contract of the Thai government with the attitude of Thai government organisations from this research study:

1. The restriction of the contractor's right to claim for an increase of direct cost and an increase of overhead cost due to force majeure in clause 11 is consistent with the attitude of Thai government organisations that want to restrict such rights.

2. The granting of five types of the contractor's claiming right in Clause 16 and Clause 22 is consistent with the attitude of Thai government organisations that do not want to restrict such rights. These rights are (1) the right to claim for an extension of construction duration due to change in scope of work, (2) the right to claim for an extension of construction duration due to force majeure, (3) the right to claim for an extension of construction duration due to employer's ineffective performances, (4) the right to claim for an extension of construction duration due to employer's interference actions, and (5) the right to claim for an increase of overhead cost due to change in scope of work.

3. The silence of the contract on the contractor's right to claim for four types of effect, which imply the restriction of the contractor's claiming rights, is consistent with the attitude of Thai government organisations that want to restrict such rights. These four types of effects are (1) an increase of direct cost due to the employer's interference actions, (2) an increase of overhead cost due to the employer's ineffective performance, (3) an increase of overhead cost due to the employer's interference actions, and (4) an increase of overhead cost due to differing site condition.

4. The silence of the contract on the contractor's right to claim for three types of the effect, which imply the restriction of the contractor's claiming rights, is not consistent with the attitude of Thai government organisations that do not want to restrict such rights. These effects are an extension of construction duration, an increase of direct cost due to differing site conditions and an increase of direct cost due to employer's ineffective performances.

From the comparison, it can be concluded that granting or restricting each type of the contractor's right to claim compensation for unfavourable effects from undesirable events in the standard contract of the Thai government contract are mostly consistent with the attitude of Thai government organisations. There are only three types of contractor's right to claim for compensation that Thai government organisations did not want to be restricted, for which the contract does not grant such a right. These three types of right are the right to claim for an extension of construction duration, an increase of direct cost due to differing site conditions, and an increase of direct cost due to employer's ineffective performances. This inappropriateness may cause Thai government organisations to be charged unnecessarily high risk premiums by contractors.

\section{CONCLUSION}

This research reveals the potential of applying choice-based conjoint analysis in construction engineering and management research, and more specifically the use of choice-based conjoint analysis to study the attitude of construction people towards the restriction of the contractor's right to claim for compensation. In this study, choice-based conjoint analysis was applied to study the attitude of Thai government organisations. The study focused on their attitudes towards the restriction of the contractor's right to claim compensation for unfavourable effects from five types of undesirable events. These events are force majeure, ineffective performances of employer, interference of the work by the employer's actions, differing site conditions, and change in scope of work.

Results of the study reveal the attitude of Thai government organisations towards the restriction of the contractor's right to claim for compensation as follows: (1) the organisations want to restrict the contractor's right to claim for an increase of direct cost in two cases, force majeure and interference in the work by employer's actions, (2) the organisations prefer to restrict the contractor's right to claim for an increase of overhead cost in all cases except for change in scope of work, and (3) the organisations did not want to restrict the contractor's right to claim for the extension of construction duration in all five cases.

This finding is useful for considering whether to grant or to restrict each type of the contractor's right to claim for compensation. Based on the data from this study, the contract between Thai government organisations and contractors should not restrict eight types of the contactor's right that Thai government organisations did not want to restrict. This study also reveals the rank of preference of the organisations for the restriction of each type of the contractor's claiming right. Of the six types of right, the right that the organisations want to restrict the most is the contractor's right to claim for an increase of direct cost due to force majeure.

Moreover, the premium that the organisations are willing to pay for the restriction of the contractor's claiming rights, in terms of the total project direct cost, is also reported. The total extra cost that the organisations are willing to pay for restricting all the six types of contractor's right to claim for compensation is $0.882 \%$. The extra cost that the organisations are willing to pay for the restriction of each type of right ranges between $0.087 \%$ and $0.210 \%$ of the total project direct cost. The data is necessary for considering whether to grant or to restrict the contractor's right to claim in the case that the organisations want to restrict such a right but the contractors do not want it to be restricted.

In addition, the data on the attitude of the organisations that was obtained from the choice-based conjoint analysis experiment was used to analyse the appropriateness of the standard contract of Thai government. The analysis reveals three types of contractor's right to claim for compensation that Thai government organisations did not want to restrict, for which the contract does not grant such a right. This inappropriateness of the contract may cause Thai government organisations to be charged unnecessarily high risk premiums by contractors.

\section{REFERENCES}

Akintoye, A.S. and MacLeod, M.J. (1997) 'Risk analysis and management in construction', International Journal of Project Management, 15(1), 31-38.

ACES/AGC (2005) Enlightened risk allocation: The twenty-first century owner's guide to cost-effectiveness, The American Council of Engineering Companies and the Associated General Contractors of America, available at: http://www.mmcd.net/ downloads/Enlightened_Risk_Allocation.pdf.

ANDI (2006) 'The importance and allocation of risks in Indonesian construction projects', Construction Management and Economics, 24(1), 69-80. 
Ashley, D.B., Dunlop, J.R. and Parker, M.M. (1989) Impact of risk allocation and equity in construction contracts, A Report to the Construction Industry Institute, Source Document 44, Austin: University of Texas.

Bing, L., Akintoye, A.S., Edwards, P.J. and Hardcastle, C. (2004) 'The allocation of risk in PPP/PFI construction projects in the UK', International Journal of Project Management, 23(1), 25-35.

Diekmann, J.E. and Nelson, C.M. (1985) 'Construction claims: Frequency and severity', Journal of Construction Engineering and Management, 111(1), 74-81.

Downs, G. and Kettle H. (2008) 'Effective risk allocation in infrastructure projects', a presentation to the New Zealand Council for Infrastructure Development Building Nations Symposium, Auckland, 14 August, available at: www.inassociation.com. au/events/NZCID08/html/documents/BellGullycommentary_ NZCIDBuildingNationsSymposium2008.pdf.

El-Sayegh (2007) 'Risk assessment and allocation in the UAE construction industry', International Journal of Project Management, 26(4), 431-438.

Hartmann, A. and Sattler, H. (2002) Commercial use of conjoint analysis in Germany, Austria, and Switzerland, Research Papers on Marketing and Retailing, No. 006, University of Hamburg, available at: www.uni-hamburg.de/fachbereiche-einrichtungen/ fb03/ihm/rp6.pdf.

Hensher, D.A., Rose, J.M. and Greene, W.H. (2005) Applied choice analysis: A primer, Cambridge: Cambridge University Press.

Jergeas, G.F. and Hartman, F.T. (1996) 'A contract clause for allocating risks', Transaction of AACE International, D\&RM.1.1D\&RM.1.3.

Kartam, N.A. and Kartam. S.A. (2001) 'Risk and its management in the Kuwaiti construction industry: A contractor's perspective', International Journal of Project Management, 22(6), 325-335.

Khan, Z.A. (1998) 'Risk premiums associated with exculpatory clauses', Master Thesis, Faculty of Graduate Study, University of Calgary.

Kumaraswamy, M.M. (1997) 'Conflicts, claims and disputes in construction', Engineering, Construction and Architectural Management, 4(2), 95-111.

Kumaraswamy, M.M. (1998a) 'Consequences of construction conflict: A Hong Kong perspective', Journal of Management in Engineering, 14(3), 66-74.

Kumaraswamy, M.M. (1998b) 'Tracing the roots of construction claims and disputes', in proceedings of Cobra 1998 conference.

Loosemore, M. and McCarthy (2008) 'Perceptions of contractual risk allocation in construction supply chains', Journal of Professional Issues in Engineering Education and Practice, 134(1), 95-105.

Mohamed, R.Z. and Hartman, F.T. (2000) 'How to reduce your project cost', AACE International Transactions, PM.15.1-PM15.7.

Orme, B. (2006) Sample size issues for conjoint analysis studies, available at: www.sawtoothsoftware.com.
Rahman, M.M. and Kumaraswamy, M.M. (2002) 'Risk management trends in the construction industry: Moving towards joint risk management', Engineering, Construction and Architectural Management, 9(2), 131-151.

Sawtoothsoftware (2007) 2007 Customer survey results, available at: http://www.sawtoothsoftware.com/education/ss/ss27.shtml.

Semple, C., Hartman, F.T. and Jergeas, G. (1994) 'Construction claims and disputes: Causes and cost/time overruns', Journal of Construction Engineering and Management, 120(4), 785-794.

Sturts, C.S. and Griffis, F.H. (2005) 'Addressing pricing: Value bidding for engineers and consultants', Journal of Construction Engineering and Management, 131(6), 621-630.

Ward, S.C., Chapman, C.B. and Curtis, B. (1991) 'On the allocation of risk in construction projects', International Journal of Project Management, 9(3),140-147.

Yogeswaran, K., Kumaraswamy, M.M. and Miller, D.R.A. (1998) 'Claims for extensions of time in civil engineering projects', Construction Management and Economics, 16(3), 283-293.

Zaneldin, E.K. (2005) 'Construction claims in United Arab Emirates: Types, causes, and frequency', International Journal of Project Management, 24(5), 453-459. 